IJAMSR 2 (11) www.ijamsr.com CrossRef: https://doi.org/10.31426/ijamsr.2019.2.11.2111

\title{
Building Character Values through Karawitan as Musical Arts Extracurricular Learning
}

\author{
Rohmadin $^{1}$, Mulyanto ${ }^{2}$, Edy Tri Sulistyo ${ }^{3}$, Sutamo Haryono ${ }^{4}$ \\ ${ }^{1,2,3}$ Master of Art Education, Post-graduate Program, Universitas Sebelas Maret, Surakarta, Indonesia \\ Email: rohmadin1995@gmail.com
}

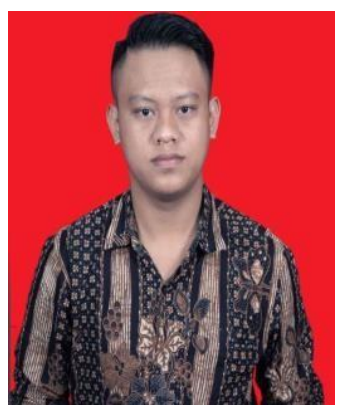

ROHMADIN

Keywords: Character bulding, karawitan musical arts.

\begin{abstract}
A B S T R A C T
Karawitan elevates the values of character education together with the preservation of traditional culture through extracurricular musical arts. This study aims to determine the values of character education contained in the learning of karawitan as musical arts extracurricular at SD Muhammadiyah 1 Surakarta. The focus of the study is to identify the values of character education contained in the extracurricular learning of musical arts in SD Muhammadiyah 1 Surakarta. The research method used was qualitative descriptive approach. The subjects of this study were teachers, students, and artists from Surakarta who are experts in musical arts. The instrument used in this study were personal data from school, archives, and documents. The results showed the values of character education contained in musical learning at SD Muhammadiyah 1 Surakarta, including: values of patience, religious, honest, tolerance, discipline, hard work, independent, curiosity, love of the motherland, respect for achievement, and responsibility. In addition to covering the values of character education, musical art can also train the abilities of students which include cognitive aspects, psychomotor aspects, and affective aspects of students at SD Muhammadiyah 1 Surakarta.
\end{abstract}

Citation: Rohmadin, Mulyanto, Edy Tri Sulistyo, Sutamo Haryono (2019). Building Character Values through Karawitan as Musical Arts Extracurricular Learning. International Journal of Advanced Multidisciplinary Scientific Research (IJAMSR) ISSN:2581-4281, 2 (11), November, ,2019, \# Art.2111 pp $1-18$ 
IJAMSR 2 (11) www.ijamsr.com CrossRef: https://doi.org/10.31426/ijamsr.2019.2.11.2111

\section{International Journal of Advanced Multidisciplinary Scientific Research (IJAMSR) ISSN:2581-4281}

\section{Introduction}

There is a rapid development in Indonesia in multiple fields. Culture in Indonesia both in terms of traditional culture and modern culture has developed alongside the education due to the midst of globalization around the world and all countries experience the same. Globalization that is very closely related to technology such as social media through internet networking (Instagram, WhatsApp, Facebook, and online games) has also affected daily lives. Therefore the effect of globalization on culture is very high. The occurrence and ongoing of globalization certainly have a positive or negative impact arising from the era of globalization. The existence of this phenomenon, the easier the variety of cultures that enter and affect various aspects of community life. Whether it's in the fields of politics, economics, education, information technology, social, arts and culture. Now it all comes back to each individual as an Indonesian citizen to be smarter and more careful in sorting out culture. Western cultural values easily enter through a variety of information media that are the current reference for today's young generation.
The younger generation is also affected by globalization phenomena. One of the younger generation is the children who are still in elementary school. The number of problems among people who are still unstable and have not been able to wisely choose and sort between good influences and bad influences. All things that are considered present and are being followed trend. In fact, not all of these things are positive. This happened also among students in SD Muhammadiyah 1 Surakarta. Students in SD Muhammadiyah 1 Surakarta generally show their interest in the current style of culture. They follow all things related to foreign culture, whether it's how to dress, hairstyle and they are also very interested in the genre of music from Korea, the K-POP band group. Another thing that is also a consideration is when the first level students are class III who follow the beginning of musical extracurricular activities. Most students are still not aware of the positive things that exist. The tendency to play gamelan is not appropriate and ethics in musical extracurricular activities is not good. Like jumping over gamelan instruments, individuals, playing percussion tabuh saron is used for slenthem or bonang barung, the volume in playing is very loud, and some students feel embarrassed when 
IJAMSR 2 (11) www.ijamsr.com CrossRef: https://doi.org/10.31426/ijamsr.2019.2.11.2111

\section{J A M S R}

\section{International Journal of Advanced Multidisciplinary Scientific Research (IJAMSR) ISSN:2581-4281}

reading texts in Javanese.

From various education level, character building most likely to be included in arts. At the second level, karawitan extracurricular activities are followed by grade IV students. The ability or skills of students begin to appear. Students who are classified as having more actual abilities also need attention like other students. Because it arises a number of problems namely students running away, quiet, pretending to be stupid, looking for attention; in an effort to seek attention from educators after doing the task, students walk while screaming, making noise, disturbing their friends. This is done by efforts to seek attention from educators and other students. If this condition is left alone it will be very detrimental to the students themselves and other friends.

Karawitan art in the Surakarta area generally has long known about traditional art of karawitan art. Today's musical art is not only for entertainment. But musical art as well as part of formal education can be seen from several institutions such as SMK N 8 Surakarta and ISI Surakarta. An educational phenomenon through musical art there are two elements that are so important to recognize namely audio and visual.
The sound produced by the playing of each instrument is then the Javanese outfit that is used to present the show. As for aspects of education that are relevant in musical art, for example the ability of a musician (another name for musician) is 1) the ability in terms of cognitive, including: the knowledge contained in the text of song; 2) ability in terms of psychomotor, including: skills in playing gamelan instruments; 3) ability in terms of affective, including: ethics when playing musical instruments.

This is in accordance with ICT-based character education organized by SD Muhammadiyah 1 Surakarta. ICT-based character education is carried out in various ways, one of several ways is musical extracurricular. Where the inculcation of the values of character education together with the preservation of traditional culture which one form is through extracurricular learning of musical arts. So from that the authors are interested in conducting research with the title "Building Character Values through Karawitan as Musical Arts Extracurricular Learning". 
IJAMSR 2 (11) www.ijamsr.com CrossRef: https://doi.org/10.31426/ijamsr.2019.2.11.2111

\section{J A M S R}

\section{International Journal of Advanced Multidisciplinary Scientific Research (IJAMSR) ISSN:2581-4281}

\section{Methods And Materials:}

Sugiyono (2013: 2) states the research method is basically a scientific way to obtain data with specific purposes and uses. There are four keywords that need to be considered namely the scientific way, data, purpose and usability that will be parameters in this study. This research has been conducted at SD Muhammadiyah 1 Surakarta Jl. Kartini No.1, RT.01 / RW.09, Ketelan, Banjarsari, Surakarta, Central Java, Indonesia. This research uses descriptive qualitative research methods. Descriptive research is collecting data based on factors that support the object of research, then analyzing these factors to look for its role (Arikunto, 2010: 151).

This study aims to determine the values of character education contained in the learning of karawitan as musical arts extracurricular at SD Muhammadiyah 1 Surakarta. The focus of the study is to identify the values of character education contained in the extracurricular learning of musical arts in SD Muhammadiyah 1 Surakarta. The research method used was qualitative descriptive approach. The subjects of this study were teachers, students, and artists from Surakarta who are experts in musical arts.
The instrument used in this study were personal data from school, archives, and documents. Research data includes the learning process of musical arts, and the values of character education. Data collection techniques used in the form of observation techniques, interviews, archives, and documents. The data analysis technique was carried out by the interakrif model. Data analysis includes data reduction, data presentation, conclusion drawing and verification. To maintain the validity of the data triangulation of sources and informant review were carried out. Data collection was carried out at SD Muhammadiyah 1 Surakarta. Then the data is analyzed and verified to review the uncertain data.

\section{Results and Discussion:}

\section{Results}

Karawitan is one of musical arts extracurricular learning at SD Muhammadiyah 1 Surakarta. It is realizing the explanation of the values of character education. The results of the study design are observation and field notes, when students play gamelan and present Javanese songs showing positive values contained in extracurricular learning of musical arts. Positive 
IJAMSR 2 (11) www.ijamsr.com CrossRef: https://doi.org/10.31426/ijamsr.2019.2.11.2111

\section{J A M S R}

\section{International Journal of} Advanced Multidisciplinary Scientific Research (IJAMSR) ISSN:2581-4281

values in question varies, including: values of patience, religious, honest, tolerance, discipline, hard work, independent, curiosity, love of the motherland, respect for achievement, and responsibility.

The results of interviews with musicians extracurricular educators at SD Muhammadiyah 1 Surakarta are of the opinion that the existence of musical extracurricular arts is expected to be able to equal the talents and interests of students at SD Muhammadiyah 1 Surakarta especially in the field of musical arts. Because extracurricular enthusiasts of musical art from year to year continue to increase both in terms of amount, quality, and quantity. Then the aim of extracurricular learning is musical art as the character building of students at SD Muhammadiyah 1 Surakarta. In delivering learning material for extracurricular musical arts in musical art. Educators have methods which include introduction, core activities, and closing. This method is used with the aim that students feel comfortable when participating in learning. Enrichment of the material is applied when there are certain activities for example such as attending the International Gamelan Festival in 2018 in Surakarta, by adding hours of practice outside the hours of extracurricular learning. Besides that, for some instruments such as bonang and vocal, the school also invites outside educators who are experts in the field to deepen the students' skills.

The results of interviews with the principal of the Muhammadiyah 1 Surakarta Elementary School argued that extracurricular activities began long ago. Only, then the program that was compiled integrated with learning and other activities began since SD Muhammadiyah 1 Surakarta became a character education elementary school. Previously, the extracurricular was separated from intracuricular and kokurikuler. Since last year (2017) extracurricular activities have joined intracuricular activities. It is expected that with this activity students have a high enthusiasm value and become one of the ways in efforts to shape the character of students. In addition to the value of enthusiasm in participating in extracurricular learning activities in musical arts, by learning Javanese gamelan and songs students learners can become aware of the character values contained in musical art which is karawitan. In addition, data obtained from interviews of several Muhammadiyah 1 
IJAMSR 2 (11) www.ijamsr.com CrossRef: https://doi.org/10.31426/ijamsr.2019.2.11.2111

\section{International Journal of Advanced Multidisciplinary Scientific Research (IJAMSR) ISSN:2581-4281}

Elementary School students in Surakarta, including students in class V and VI semester I. They explained that musical art has character values such as cultural love, as a young generation they also feel obliged to preserve traditional culture, namely musical arts. Then the value of mutual cooperation, students in learning musical arts have a way of collaboration between friends in presenting or playing gamelan. Even though there are a lot of extracurricular activities at SD Muhammadiyah, they feel happy and proud to take part in extracurricular activities in musical arts because besides getting knowledge they also get experience.

\section{Discussion}

Karawitan as musical art is one of the traditional arts that needs to be preserved. In addition to being the culture of an area of karawitan art, it is a characteristic of a nation. According to Soedarsono (1992: 14), musical instrument in general is an art that includes all branches of art that contain elements of beauty, subtle and complicated or confounding. In karawitan there are basic rules such as laras, pathet, technique, and rhythm. The system of values and rules owned by karawitan as a form of difference with other cultures, the karawitan is a local cultural art that has special characteristics. Another opinion was expressed by Rejomulyo (2010: 6). Karawitan art is a combination of vocal singing of songs in traditional way and instrumental sounds (gamelan). The beautiful sound comes from humans with a vocal instrument, and from an instrumental gamelan. The beauty of the sound obtained from humans due to the mastery of techniques by good vocals, while the beauty of the sound produced from the gamelan (instrumental) due to the mastery of good and compact / harmonious garap tabuhan technique according to the theory with the practice of its implementation supported by the expression of soul / feeling smooth.

Positive values contained in musical art can be seen when presenting Javanese songs and playing each different gamelan instruments together. In correlation each different gamelan instrument has its own role and function which results in a good and solid presentation. The combination of vocal or song performances and different gamelan instruments can be analogized as a form of national unity and unity as the motto of the Indonesian: Bhinneka Tunggal Ika. 
IJAMSR 2 (11) www.ijamsr.com CrossRef: https://doi.org/10.31426/ijamsr.2019.2.11.2111

\section{J A M S R}

\section{International Journal of} Advanced Multidisciplinary Scientific Research (IJAMSR) ISSN:2581-4281

According to Rejomulyo (2010: 11), gamelan has many functions in life, namely: 1) as a means of entertainment 2) as a means of education 3) as a means of ceremony 4) as a means to work on spiritual wigati (in / main) about the human mind. Another opinion was also explained by Suwardi Endraswara (2009: 70) classifying learning psychology in Javanese song into several aspects including, inner expression, arousing clear reasoning, smoothing feeling, and harmonizing desires. Therefore, musical art has a positive character value. Positive values in question include; values of patience, religious, honesty, tolerance, discipline, work ethic, independence, democratic, curiosity, patriotism, respect for achievement, love for peace, and responsibility.

\section{Character Values Contained in Karawitan as Muscial Arts Extracurricular Learning}

\section{Patience Value}

The value of patience in musical arts occurs when playing gamelan and when extracurricular activities of musical arts take place. This patience value appears when students wait their turn to play the gamelan. Because the extracurricular of karawitan art at SD Muhammdiyah is attended bythird, fourth, fifth and sixth grade in the first semester. The total number of students participating in extracurricular activities reached 70 students. Each group in learning to play gamelan consists of 15-20 students. So to be able to participate in learning students must wait patiently for the next turn.

The value of patience also lies in the gamelan instrument, the gong instrument. For elementary level, it is usually done by two students for kempul and gong instruments. Kempul own and gong themselves. On the gong instrument. Students can practice patience, because in the genging gong is played once in the form of gending both gangsaran, lancaran and other forms of gending. In lancaran play to perform some musical arrangement, participants who play gong instruments must wait for a count of sixteen to be able to play the instruments. The following explanation uses the notation is presented below:

$$
\cdot 6 \cdot \overline{5}+3 \cdot \overline{2}+3 \cdot \overline{2} \cdot \overline{6} \cdot(\overline{5})
$$


IJAMSR 2 (11) www.ijamsr.com CrossRef: https://doi.org/10.31426/ijamsr.2019.2.11.2111

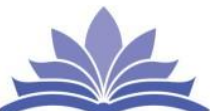

I J A M S R

\section{International Journal of Advanced Multidisciplinary Scientific Research (IJAMSR) ISSN:2581-4281}

The mark applies to kenong instruments, the mark applies to kempul instruments, and the mark applies to gong instrument. It can be understood that the gong instrument is tapped last, so students must implement the value of patience by doing "tu wa ga nong, tu wa ga nong, tu wa ga nong, tu wa ga gong" in addition to practicing patience, the gong instrument also serves to provide a sign that the gending is at the last point to return to the initial notation again and it reverses back to again and again.

\section{Religious Value}

The value of religious side in musical arts occurs when the verse on each song taken place. A lot of verse in karawitan song were composed in spiritual way after the author got a very intense religious message of their life. Below is one of song played in karawitan as musical arts that contains a high sense of religious values.

\begin{tabular}{|c|c|c|}
\hline \\
\hline \multicolumn{2}{|c|}{ Buka: $\quad .3 .1 .3 .1 .2 .6$} & Lancarass Wilanging Jagad Lr Pl Pt Nem \\
\hline & \\
\hline & \\
\hline & \multicolumn{2}{|c|}{ 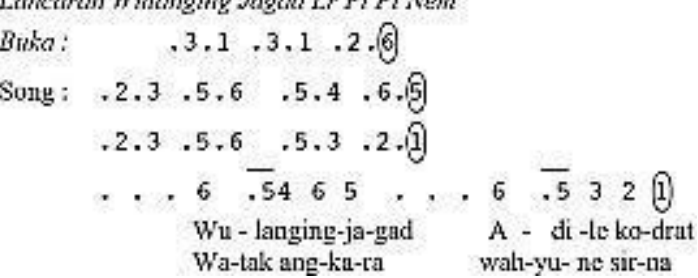 } \\
\hline
\end{tabular}

Several times the opportunity was used by the art team at SD Muhammadiyah 1 Surakarta. One of them was on 7 March 2018 at the Golden Boutique Hotel, Central Jakarta. In the opening ceremony of the art facilities facilitation workshop in the education unit in 2018. The event was attended by the Minister of Education and Culture, echelon I officials in the Ministry of Education and Culture, Commission $\mathrm{X}$ of the Republic of Indonesia House of Representatives, Director General of Culture Tax, and principals at elementary, junior and senior high school recipients facilitation of art facilities throughout Indonesia. On this occasion, the art team at SD Muhammadiyah 1 Surakarta presented the fragment Anoman Duta scene in performance arts of public cultural practice.

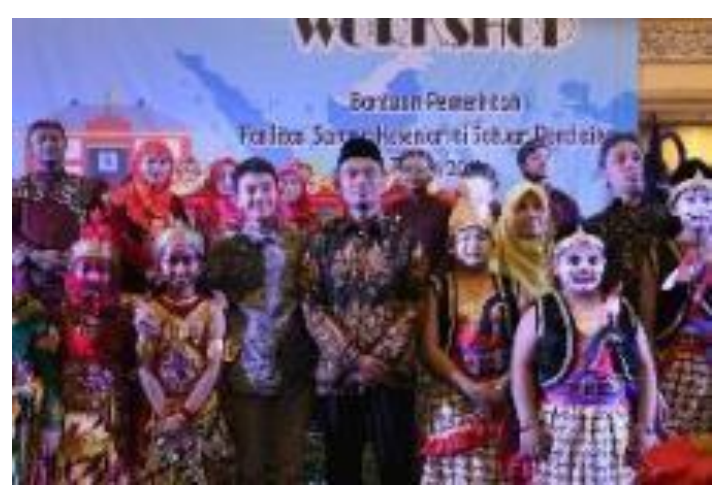

Figure 1. After the performance of the Anoman Duta fragment is completed the student and extracurricular companion take a picture with the Minister of Education and Culture. 
IJAMSR 2 (11) www.ijamsr.com CrossRef: https://doi.org/10.31426/ijamsr.2019.2.11.2111

\section{J A M S R}

\section{International Journal of} Advanced Multidisciplinary Scientific Research (IJAMSR) ISSN:2581-4281

Source: Document of SD Muhammadiyah 1 Surakarta.

In connection with the performance, one of the musical art material presented was Lancaran Wulanging Jagad. Refers to the value of religious character education. Agung as a teacher / educator of extracurricular arts said that when performing in Jakarta, the group included students performing Tahiyatul Masjid prayers at the Istiqal Mosque, dawn prayers and reading the Qur'an to strengthen religious and visit tourist destinations of the National Monument (Monas) as the destination symbol of Indonesia.

"Saya merasa sangat senang denganantusiasme siswa dan orang tua, selain itu kita bisa belajar ayat-ayat Allah. Ayat Allah ada qauliyah dan kauniyah. Qouliyah berarti ayat yang difirmankan Allah dalam al Qur'an, sedangkankan kauniyah ayat atau tanda wujud di sekeliling kita, fenomena alam, kejadian di sekitar kita, kata Agung”.

According to him, Lancaran Wulanging Jagad is reflected in the concept of Hastha Brata while hastha has a meaning of 8 and brata has a meaning of behavior / action / self-control / behavior / character. Reflected in the form of: a) Fire / Geni, meaning the leader must be able to give urup and urip.

b) Water / Banyu / Ocean, meaning leaders provide solutions in solving problems.

c) Wind / Maruta, meaning leaders must be wise, fair, and equitable.

d) Sun / Srengene, meaning the leader must give life.

e) Cloud / Mendhung, meaning leaders must be authoritative.

f) Moon / Mbulan, meaning the leader is able to guide / bring enlightenment.

g) Earth / Bantala, the meaning of that leader is devotion to the nation and state and always obedient to religion.

Whereas in the vocal text (cakepan) lancaran wulanging jagad adalah wulanging jagad adile kodrat, angkara murka wahyuni sirna. Based on the above opinion that as humans we must always strengthen our faith and religious values through our surroundings, natural phenomena, and God's verses that are analogous or packaged in a work of performance the verse on Lancaran Wulanging Jagad. 
IJAMSR 2 (11) www.ijamsr.com CrossRef: https://doi.org/10.31426/ijamsr.2019.2.11.2111

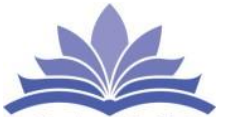

\section{International Journal of \\ Advanced Multidisciplinary Scientific Research (IJAMSR) ISSN:2581-4281}

I J A M S R

\section{Honesty Value}

The need to present musical instruments in general, artists or artists must have a happy feeling, not feeling angry, hate, and so forth. Same is the case for students when joining extracurricular learning in musical arts. Students who are feeling that they have no burden or problems, they actively participate in learning and understand quickly. On the other hand, participants who have problems or burdens both in school or outside of school, they cannot concentrate well and often make mistakes. Some students admit that when they make mistakes in playing gamelan, they claim that they have a lot of school work to do. Events like this indirectly teach students honesty about what is being felt so that it can affect other activities in both formal and non-formal activities.

\section{Tolerance Value}

The value of tolerance is reflected in the musical art one of which is in the musical composition of the attitude to guard the ego or emotional when playing a gamelan instrument. Students should not be allowed to play gamelan instruments with a very loud volume, thus making the concentration of other students disturbed. Each student must pay attention to the right, left, front, and back.

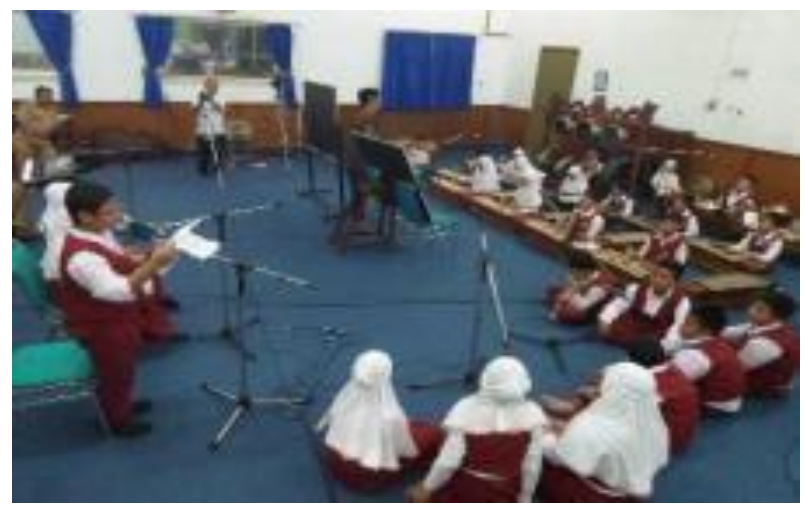

Figure 2. Participants carry out broadcasts on Radio Republik Indonesia Surakarta in commemoration of National Education Day

Source: Document of SD Muhammadiyah 1 Surakarta

Seen in the Figure above based on the settings of the gamelan instruments are close together and there are those in front, groin, right, and left. Thus the value of tolerance is reflected by the attitude of students to always remind their friends to consider the volume of gamelan instruments so that the instruments are maintained with one another. 
IJAMSR 2 (11) www.ijamsr.com CrossRef: https://doi.org/10.31426/ijamsr.2019.2.11.2111

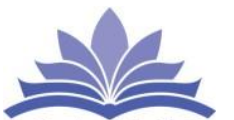

\section{International Journal of Advanced Multidisciplinary Scientific Research (IJAMSR) ISSN:2581-4281}

\section{Discipline Value}

The value of discipline character is reflected in the extracurricular learning of musical arts. First, in fact students are on time to attend extracurricular activities. Then discipline in gamelan is that students must be aware of the tempo and play according to the notation given. For example, participants have different tempo and playing gamelan instruments not according to the notation, the gending presentation will not go well. Therefore awareness or discipline understands the tempo, understands the notation correctly and discipline when to play gamelan with loud and slow volumes.

\section{Work Ethic Value}

The containing work ethic values of extracurricular learning of musical arts is the performing arts at the beginning of the semester of the new school year or often referred to as Awalussanah. In addition to other performing arts performances also participated in the event. Such as dance, music, martial arts, and reading the verses of the Holy Qur'an by students. Specifically for musical arts, preparations for presenting a work or gending that they have learned during the extracurricular learning activities of musical art, will be staged in order to provide experience to students when learning traditional musical arts.

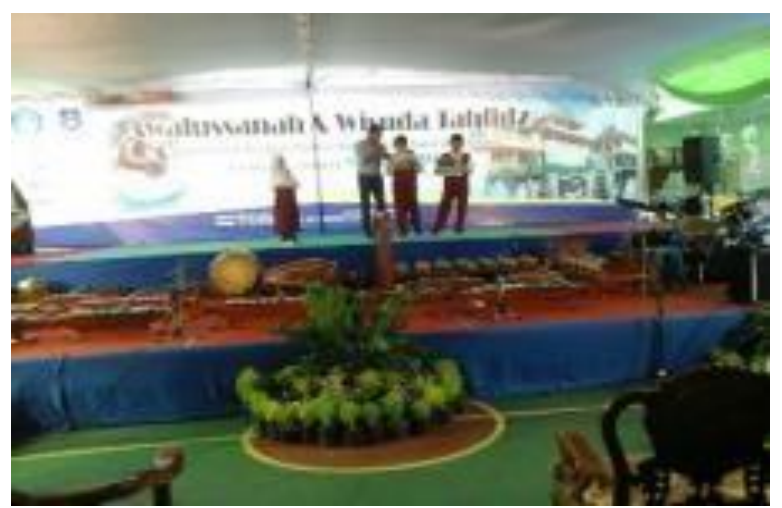

Figure 3. The initial stage of elementary school Muhammadiyah 1 Surakarta in the school yard when performance began

Source: Document of SD Muhammadiyah 1 Surakarta.

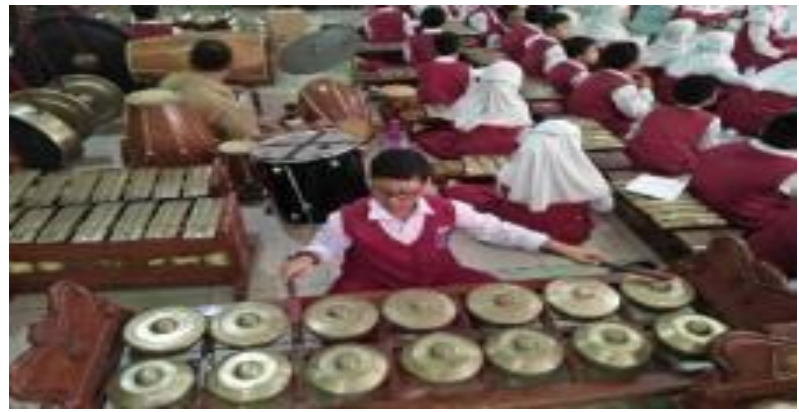

Figure 4 . The process of preparing for the initial stage

Source: Document of SD Muhammadiyah 1 Surakarta. 
IJAMSR 2 (11) www.ijamsr.com CrossRef: https://doi.org/10.31426/ijamsr.2019.2.11.2111

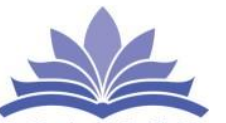

\section{International Journal of Advanced Multidisciplinary Scientific Research (IJAMSR) ISSN:2581-4281}

Considering the maximum performance of students to get enrichment of learning materials through the exercise process outside of extracurricular learning hours. The value of hard work is embedded in this activity. Participants were very enthusiastic and enthusiastic about working hard to prepare for the show with exercises and trying to memorize some material that they were able to memorize.

\section{Independence Value}

Besides being active in learning activities in the school environment. Students who take part in extracurricular musical arts activities also participate in other events such as the macapat competition. Musical art teaches about the skills, knowledge, and taste that are summarized in playing the gamelan instruments and singing Javanese songs or vocal texts contained in the learning material. Some participants who are seen to have more abilities than their friends in general will be boiled by educators to be screened for shows outside of school including macapat competitions and other traditional competition.

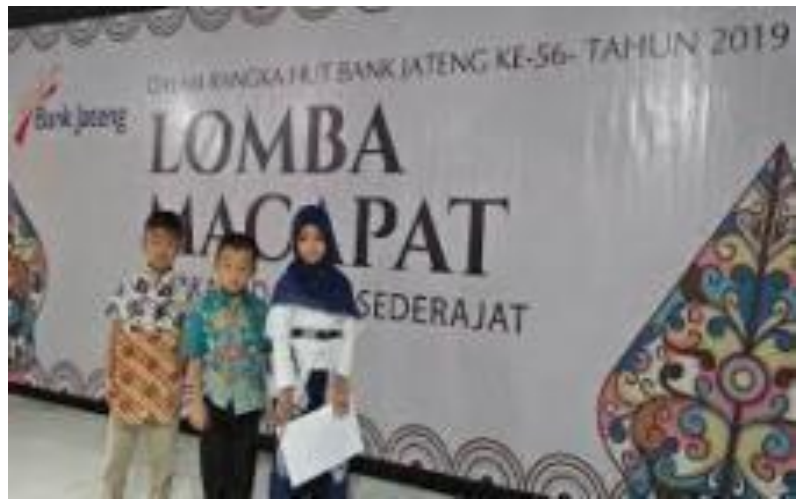

Figure 5. Taking a photo after participating in the Soloraya macapat elementary and junior high school in the Central Java Bank Slamet Riyadi Surakarta

Source: Document of SD Muhammadiyah 1 Surakarta.

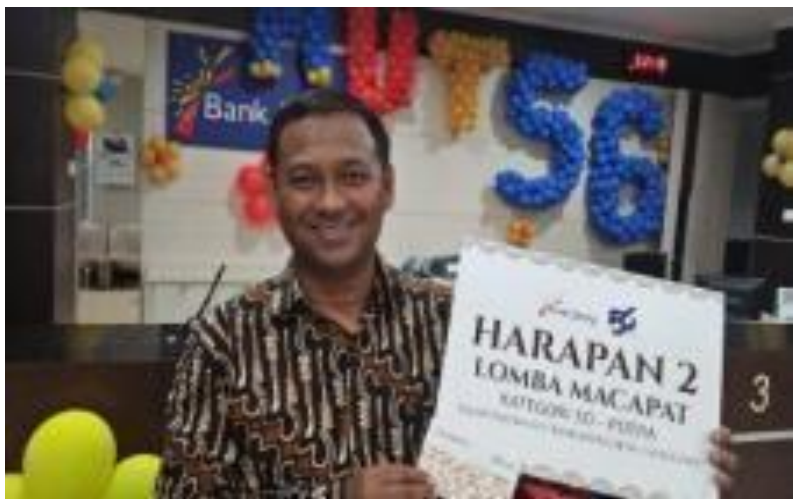

Figure 6. After the announcement of the macapat race Elementary and junior high schools throughout elementary and junior high school in the Central Java

Source: Document of SD Muhammadiyah 1 Surakarta. 
IJAMSR 2 (11) www.ijamsr.com CrossRef: https://doi.org/10.31426/ijamsr.2019.2.11.2111

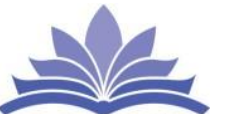

\section{International Journal of Advanced Multidisciplinary Scientific Research (IJAMSR) ISSN:2581-4281}

Based on the photo above, the students who took part in the competition were named Galen Bianco Hartono, Gibran Maheswara Javas Setyawan, and Kiarra Ajirani. They are chosen based on their ability in good sound aspects and can follow the macapat song that uses tones in the gamelan. One of the results of participating in the competition produced results as the hopes of winning 2 macapat-elementary school men's competition category, Gibran Maheswara Javas Setyawan compounds. This activity is very good to support student experience and to train students' independent attitude to always learn confident and feel they have the soul of traditional art which is reflected in their character.

\section{Curiousity Value}

Many students and the surrounding community know about musical arts at home and abroad. Musical art has an appeal to Western people because of its uniqueness than musical art. Western music (orchestra) at the time of serving must be right at the beat and bound to the conductor. But in musical performances it only uses visual interaction and uses the taste that every artist has. And there are some instruments how to beat it is not always right on the beat.
There is a terminology in karawitan as musical art namely gandhul. And in terms of pitch there are also differences. If the interval of the interval in the art of music, every instrument that has a melodic song tends to have the same frequency range such as 440 hertzz. While musical instruments in each instrument have tones with intervals with different frequencies each gamelan instrument, but when played together gamelan instruments produce sounds that are very harmonious. This is one of the reasons why Westerners are attracted to the traditional arts of karawitan and presented as traditional performance.

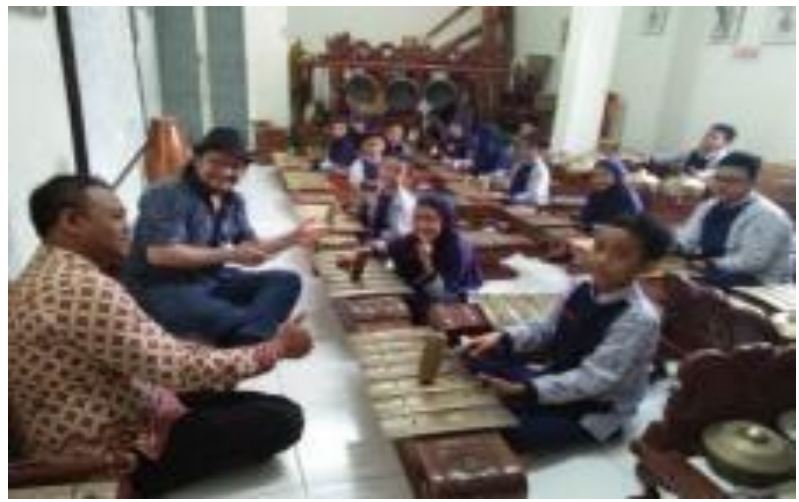

Figure 7. On the sidelines of extracurricular learning attended by guests Gabriel Laufer from Belgium.

Source: Document of SD Muhammadiyah 1 Surakarta. 
IJAMSR 2 (11) www.ijamsr.com CrossRef: https://doi.org/10.31426/ijamsr.2019.2.11.2111

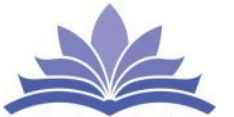

I J A M S R

\section{International Journal of Advanced Multidisciplinary Scientific Research (IJAMSR) ISSN:2581-4281}

With events such seen in Figure 7 will indirectly stimulate students' curiosity. Why is a person from Belgium interested in musical arts, and why he is pleased to witness extracurricular learning activities for musical arts in SD Muhammadiyah 1 Surakarta. Thus the value of curiosity famous through the existence of musical art at home and abroad.

\section{Patriotism Value}

In commemoration of the 74th birthday of the Republic of Indonesia, SD Muhammadiyah 1 Surakarta has a variety of ways to enliven the anniversary of the Republic of Indonesia's Independence in 2019. One of them is by presenting national songs using several gamelan instruments, such as demung, saron, kendhang, kempul, and gong. A total of 8 students, 9 educators, and 10 staff employees present the national song of Semangat Juang 45, Sang Surya, Hari Kemerdekaan, Maju Tak Gentar, and Syukur.

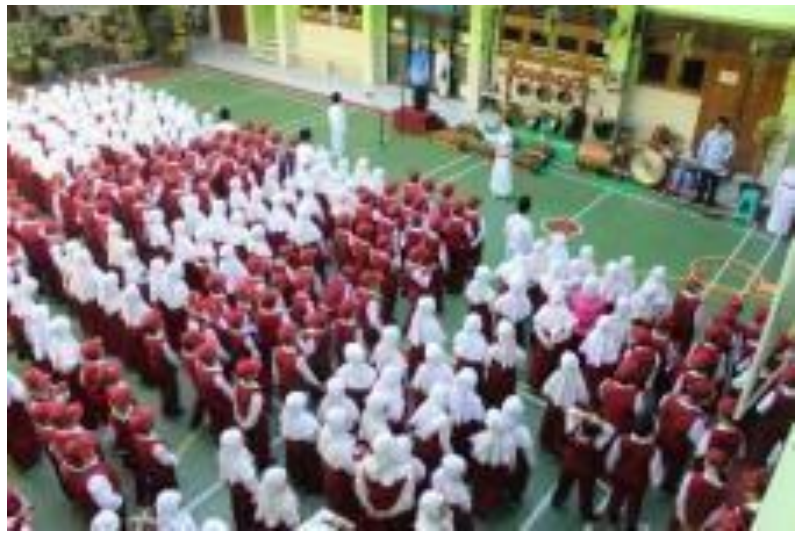

Figure 8. Some gamelan instruments during the ceremony

Source: Document of SD Muhammadiyah 1 Surakarta.

This activity was first carried out by SD Muhammadiyah 1 Surakarta by presenting gamelan and play some songs of karawitan arrangement in the ceremony. Besides aiming to love the traditional culture of karawitan art is to foster a nationalist sense of love for the motherland through the national songs that are presented.

One example of the lyrics to the song Lancaran Semangat Juang 45 is as follows: 
IJAMSR 2 (11) www.ijamsr.com CrossRef: https://doi.org/10.31426/ijamsr.2019.2.11.2111

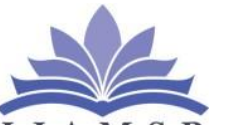

I J A M S R

\section{International Journal of Advanced Multidisciplinary Scientific Research (IJAMSR) ISSN:2581-4281}

"Galo kae genderane kumlebet angawe-awe, Abang Putih sang Dwiwarna iku lambang sejatine, Negara kita wus merdika, Kang adhedhasar Pancasila, Dumadi kalaning tanggal, Pitulas Agustus sasine, Nuju taun sewu sangangatus patang puluh lima, Rambate rata hayu, Holobis kontul baris, Rambate rata hayu, Holobis kontul baris, Tumandang bareng maju nunggal tekad rahayu, Merdeka merdeka merdeka, Bumi klairanku, Merdeka merdeka merdeka, Wus tetep merdika".

One of the Javanese music with musical art that can be packaged to be a media in fostering the love of students towards the homeland of Indonesia.

\section{Respect for Achievement Value}

Extracurricular art of karawitan as musical arts learning in various environment can be stated the most prominent activity of the other extracurricular activities in SD Muhammadiyah 1 Surakarta. Evidenced by the many documents about extracurricular musical performances in various school and non-school events.

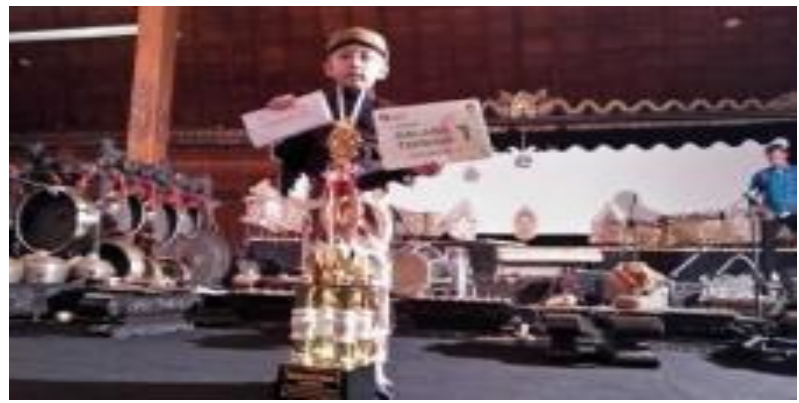

Figure 9. Gibran Maheswara, student of SD Muhammadiyah 1 Surakarta won the best champion of 2019 Little Mastermind Festival from Surakarta City Culture Office.

Source: Documents of SD Muhammadiyah 1 Surakarta.

Talent in the art world is found in the students of Gibran Maheswara Javas Setyawan like it can be seen in Figure 9 when he won the festival. In addition to being active in the school environment to study education, also being active in the arts environment. His talent in playing the gamelan is also balanced with talent as a puppeteer. Some of the achievements of these students may be an inspiration to other students and can appreciate the achievements of anyone, despite differences in age younger and older. 
IJAMSR 2 (11) www.ijamsr.com CrossRef: https://doi.org/10.31426/ijamsr.2019.2.11.2111

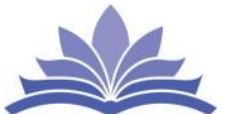

I J A M S R

\section{International Journal of Advanced Multidisciplinary Scientific Research (IJAMSR) ISSN:2581-4281}

\section{Responsibility Value}

Overall, every gamelan instrument in musical art has the same important role. Some gamelan instruments have a very important responsibility role. In terms of its function as a sign and leader in the overall musical karawitan composition serving.

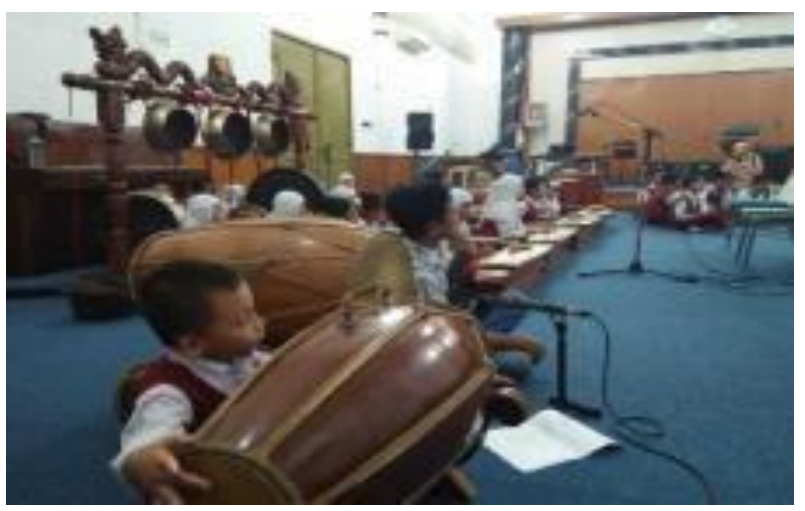

Figure 10. Students carry out broadcasts on Radio Republik Indonesia Surakarta in commemorating national education day

Source: Document of SD Muhammadiyah 1 Surakarta.

Based on the Figure 10, it should be noted based on the play of karawitan, one of the students is on the gamelan instrument, the kendhang ciblon instrument. This instrument includes instruments that have a very important role, namely as a regulator of tempo, rhythm, beginning and stopping. The responsibility of a person who plays this instrument is very large, because it relates to success in presenting gending and a sign to other friends about the way the dish and other elements. Thus the value of responsibility lies with the gamelan instrument, the kendhang ciblon instrument. The performance is quite attractive and viewers can feel the values bringing in the performance of karawitan itself.

\section{Conclusion:}

The study has been conducted and the results were analyzed in comprehensive way. Based on the results of the analysis and discussion of the data obtained, the author can make conclusions about the values of character building as a part of education practice in learning karawitan as extracurricular musical arts at SD Muhammadiyah 1 Surakarta.

The results of this study indicate that the process of implementing extracurricular learning at SD Muhammadiyah 1 Surakarta shows the enthusiasm and sense of belonging of students to the traditional art of karawitan art, and the activity runs well in terms of objectives, 
IJAMSR 2 (11) www.ijamsr.com CrossRef: https://doi.org/10.31426/ijamsr.2019.2.11.2111

\section{J A M S R}

\section{International Journal of} Advanced Multidisciplinary Scientific Research (IJAMSR) ISSN:2581-4281

materials, implementation, methods, media, educators, students, and evaluations. The results of the extracurricular learning activities of the karawitan as musical arts extracurricular are manifested in various performances such as the initial stage, broadcast on Radio Republik Indonesia Surakarta, participating in the Macapat competition, and other events related to karawitan art. All of these activities are aimed at providing students' experiences and practicing self-confidence that can be implemented in daily life.

Music learning activities can train students' abilities which include cognitive aspects, psychomotor aspects, and affective aspects. All about knowledge, skills / skills, and about the feelings of students, summarized in the extracurricular learning of karwitan art both in terms of gamelan instruments and meaning in vocal / song texts. The values of character education contained in the extracurricular learning of musical arts include: the value of patience, religious, honest, tolerance, discipline, hard work, independent, curiosity, love of the motherland, respect for achievement, and responsibility.

\section{Acknowledgments:}

Acknowledgments and awards are given from author to the Editorial Board and editors at the International Journal of Advanced Multidisciplinary Scientific Research(IJAMSR). Author also would like to address acknowledgement to:

a) Universitas Sebelas Maret Surakarta

b) Post-graduate Faculty, Art Education Master Program, Universitas Sebelas Maret

c) Head of Art Education Master Program Dr. Mulyanto, M. Pd.

d) Supervisor 1 Dr. Sutarno Haryono, S. Kar., M. Hum.

e) Supervisor 2 Dr. Edy Tri Sulistyo, M. $\mathrm{Pd}$.

f) The Head of SD Muhammadiyah 1 Surakarta Sri Sayekti, M. Pd.

g) Extracuricular Theacher of Karawitan as Musical Art in SD Muhammadiyah 1 Surakarta Agung Sudarwanto, M. Sn.

h) Staff of Teachers in SD Muhammadiyah 1 Surakarta.

i) Students in SD Muhammadiyah 1 Surakarta. 
IJAMSR 2 (11) www.ijamsr.com CrossRef: https://doi.org/10.31426/ijamsr.2019.2.11.2111

\section{J A M S R}

\section{References}

1) Arikunto, Suharsimi. 2002. Prosedur Penelitian Suatu Pendekatan Prakter. Jakarta: PT Rineka Ciptas

2) Endraswara, S. 2013. Metodologi Penelitian Sastra. Yogyakarta: CAPS

3) Rejomulyo.2010.Pengetahuan Seni Karawitan Elementer.Yogyakarta: Sanggar Seni Karawitan Branta Laras.

4) Soedarsono, 1992. Pengantar Apresiasi Seni. Jakarta: Balai Pustaka

5) Sugiyono. 2013. Metode Penelitian Kuantitatif, Kualitatif dan $R \& D$. Bandung: PT Alfabet. 